\title{
Effectiveness of Dosage Forms with Flurenizide in Preventive Care and Treatment of Dangerous and Controlled Infectious Diseases
}

\author{
Olyana I. Mykhalyk \\ Pharmaceutical Chemistry Faculty of Continuing Education Lviv National Medical University Danylo Halytskyi, Lviv 79010, \\ Ukraine
}

\begin{abstract}
Creation of an efficient and safe medication is based on the knowledge of the world's best achievements in medicine and pharmacy. Development of new original medications and dosage forms, study of their specific medicinal properties, application and advantages over well-known brands are important for achieving a high quality medical assistance. The innovative product—original Ukrainian substance Flurenizide served as the basis for new dosage forms (solid, semisolid and liquid) intended for preventive care and treatment of dangerous and controlled infectious diseases for human and veterinary medicine.
\end{abstract}

Key words: Flurenizide, antimicrobial, antiviral, antiseptic properties, dosage forms.

\section{Introduction}

Development and introduction of new efficient antimicrobial, antiviral and antiseptic medications into medical practice is a relevant task today. Variety of microorganisms, their ability to mutate and create forms which are resistant to existing chemotherapeutic medications urges us to seek new and more effective medications for prevention and treatment of infectious diseases. In the early 1990s at the Lviv State Medical Institute received an organic compound, patented under the name "Flurenizyd" $d^{T M}$, Pharmaceutical and Medicines that Are Used to People and Animal" [1].

Flurenizyd registered in the State Register of medicines Ukraine as a new drug in original Ukrainian antytuberkulozen and antimicrobial activity (registration No. P.10.00/02305 from 12.10.2000 p.) [2].

Corresponding author: Olyana I. Mykhalyk, candidate of Pharmaceutical Sciences, associate professor, research fields: development and research of different dosage forms based substance Flurenizyde.

\section{Materials and Methods (Information Search Scientific Literature)}

A profound analysis of patent information of Ukrainian and foreign scientists showed that fluorine use in medicine and pharmacy is promising. There are effective substances among them which are suggested for preparing readymade dosage forms and those which have already been applied in production (Florenal, Amixin, etc.).

Research methods were microbiological, pharmacological, pharmaco-technological and clinical trials.

Flurenizyd, New Ukrainian drug, has a broad spectrum of antimicrobial activity, acting on mycobacterium Myc. tuberculosis $H_{37} R v$, Chlamydia trachomatis and other (Table 1).

In the experiment, Flurenizyd is effective in type and mutated forms of Mycobacterium tuberculosis. Controlling antytuberkulozen drug activity was Izoniazyd. Microbiological, pharmacological and clinical studies of some fluorenilidenhidrazydiv are described [3]. 
Table 1 The spectrum of antimicrobial activity Flurenizydu in experiments in vitro [3].

\begin{tabular}{|c|c|c|}
\hline Microorganisms & & $\begin{array}{l}\text { Concentration } \\
(\mathrm{mkg} / \mathrm{mL})\end{array}$ \\
\hline \multirow{3}{*}{ Gram-positive cocci } & Staphylococcus aureus 201189 & $12.5 \sim 100.0$ \\
\hline & Staphylococcus album & $6.5 \sim 100.0$ \\
\hline & Staphylococcus epidermidis & $6.5 \sim 100.0$ \\
\hline \multirow{12}{*}{$\begin{array}{l}\text { Gram-positive } \\
\text { bacillus wrong }\end{array}$} & Myc. tuberculosis $H_{37} R v$ & 0.078 \\
\hline & Strain, freshly-isolated of patients with pulmonary tuberculosis resistant to Ethionamidum & 12.5 \\
\hline & Strain, freshly-isolated of patients with pulmonary tuberculosis resistant to Streptomycin & 12.5 \\
\hline & Strain, freshly-isolated of patients with pulmonary tuberculosis resistant to Kanamycin & 100.0 \\
\hline & Strain, freshly-isolated of patients with pulmonary tuberculosis resistant to Isoniazid & 6.25 \\
\hline & Strain, freshly-isolated of patients with pulmonary tuberculosis resistant to Rifampicin & $6.0 \sim 100.0$ \\
\hline & Strain No. 3421 with dual resistance (to Ethambutol and Streptomycin) & $12.5 \sim 50.0$ \\
\hline & Strain No. 1274 with dual resistance (to Ethambutol and Streptomycin) & $12.5 \sim 50.0$ \\
\hline & Ultra small bacteria $H_{37} R v$ & 1.625 \\
\hline & Ultra small mycobacteria [44) & $3.0 \sim 100.0$ \\
\hline & Revertants of Mycobacterium Ultra small [44] & 6.5 \\
\hline & Myc. Bovinus & 5.0 \\
\hline \multirow{8}{*}{$\begin{array}{l}\text { Gram-negative } \\
\text { facultative anaerobic } \\
\text { bacillus }\end{array}$} & Klebssiella & $12.5 \sim 100.0$ \\
\hline & Proteus & $12.5 \sim 100.0$ \\
\hline & Pseudomonas aeruginosa 2198 (1987) & $12.5 \sim 128.0$ \\
\hline & Shigella & 100.0 \\
\hline & Escherichia coli & $12.5 \sim 250.0$ \\
\hline & Chlamydia trachomatis, LGV & $5.0 \mathrm{mg} / \mathrm{embryo}$ \\
\hline & Mycoplasma hominis & 5.0 \\
\hline & Ureaplasma genitalium & 5.0 \\
\hline
\end{tabular}

For the first time, high activity antytuberkulozen Flurenizydu on sensitive and resistant strains of MBT (Mycobacterium tuberculosis) confirmed at the Central Research Institute of the Ministry of Health Tuberculosis [4].

Enhanced microbiological research Flurenizydu also held at the Lviv Institute of Epidemiology and Health and is part of research topics: "Examine tuberculostatic effect was first synthesized drugs of fluorene and to develop schemes to their use for the treatment of tuberculosis", No. state registration 0195U025270 and "develop new methods of diagnosis and treatment mycobacterioses", No. state registration 0196U009405 [5-11].

\section{Result and Discussion}

Effective substance with a broad spectrum is Flurenizide, introduced into medical practice in Ukraine in 2000. We have developed an effective dosage forms (solid, soft, liquid) with Flurenizydom to prevent and treat infectious diseases.

\subsection{Flurenizide Pills}

The $0.05 \mathrm{~g}$ and $0.15 \mathrm{~g}$ Flurenizide pills have been designed by authors and standardized at Danylo Halytskyi Lviv National Medical University under the supervision of Doctor of Pharmacology, Professor L. I. Petrukh, tested and standardized regulations in enterprises [12-14].

These pills prescribed for treatment of all types of tuberculosis of grown-ups and children, latent silicotuberculosis; for treatment of urogenital chlamydiosis, ureaplasmosis and mycoplasmosis; chlamydia infection in chronic pyelonephritis patients; complex therapy of eczema and syphilis patients. The basis of Urogenital candles is Flurenizide in hard dosage form has been included into "National List of Main (Vital) Medications and Medical Products" 
Table 2 Evaluation of the effectiveness of vaginal suppositories of $0.1 \mathrm{~g}$ Flurenizyd [32].

\begin{tabular}{lll}
\hline \multirow{2}{*}{ Criteria of efficacy } & \multicolumn{2}{c}{ Evaluation of efficacy } \\
\cline { 2 - 3 } & Number & Percentage (\%) \\
\hline High efficiency (1 point) & 26 & 86.7 \\
Moderate efficiency (2 points) & 4 & 13.3 \\
Low efficiency (3 points) & - & - \\
Lack of efficiency (4 points) & - & - \\
\hline
\end{tabular}

(Group J04A "Mycobacteria Affecting Products. Antituberculosis Medications") [15, 16]. The features Flurenizydu use in tablet form for oral use, immediate and remote use efficiency of chemotherapy in adult patients with chronic, mostly destructive, pulmonary tuberculosis, including the release of drug-resistant mycobacteria. Reasonable new ways to treat pathologies using Flurenizydu based on consideration of the sensitivity of Mycobacterium tuberculosis drug activity and quantities antymikobakteriynoyi blood.

Proven efficiency in the use Flurenizydu kompleksniy himioterapiyi tuberculosis respiratory organs in pupils residing in contaminated territories radionuklidamy. The results of research work successfully used in antytuberkulozen health facilities [17-28].

\subsection{Suppositories}

\section{Suppositories with Flurenizyde} farmakotechnologichno developed and put into production and medical practice [3, 29-36]. Efficiency Flurenizydom suppositories of $0.1 \mathrm{~g}$ (for women) and Flurenizydu pills of $0.15 \mathrm{~g}$ (for men) are proved in the case of infectious and inflammatory diseases and akusherstvi hinekoloriyi and urology [37-50].

Flurenizide positively decreases the level of free-radical acidification and activates fermentative link of antioxidant protection system, quickly eases the morphological picture of inflammatory process in endometrium and has a positive impact on the ultrastructure of endometrial stroma. We have proved the expediency of including Flurenizide into preventive care for pyoinflammatory complication of $\mathrm{C}$-sections in obstetric patients who live in territories with insignificant radiation pollution. The preparation boasts of its high effectiveness in treatment of urogenital chlamydiosis with immune modulating effect and no side effects.

The perception of the body of vaginal suppositories of $0.1 \mathrm{~g}$ Flurenizyd based on subjective symptoms and objective clinical data evaluated by expert researchers as "very good" at $100.0 \%$ of cases.

Adverse reactions during clinical trials Flurenizydu were found. ELISA results obtained after treatment Flurenizydom indicate chlamydia eradication of the pathogen in $86.6 \%$ of patients [32].

Noted Flurenizyd positive synergistic effect on other organs and body systems. Comprehensive treatment using Flurenizyd pills of $0.15 \mathrm{~g}$ and vaginal candles to $0.1 \mathrm{~g}$ results in the correction of humoral, cellular immunity and nonspecific resistance microorganism. The drug helps restore reproductive health and can be used in the departments of women's clinics, gynecological and maternity departments, centers of reproductive health of the family [32].

Found that Flurenizydu use in treatment of reactive arthritis, combined with chronic urogenital chlamydiosis is effective, positive impact on the course of joint syndrome, the results of clinical and laboratory parameters. Flurenizyd antyhlamidiynyy has a pronounced effect significantly reduces the number of patients diagnosed with DNA (deoxyribonucleic acid) Chl. trachomatis IgG antibody titer and the IgA and to Chl. trachomatis after treatment $[37,42]$.

\subsection{Soft Pharmaceutical Form}

1\% Flurenizide eye ointment, recommended for treatment of burns and bacterial diseases of 
cornea [51-54]. Experiments show that in complex eye burns therapy it decreases the duration of epithelization and increases acuity of vision, has an antibacterial, anti-inflammatory and healing effect, decreases the level of complications.

Designed improved, pathogenetic complex method of treatment of eczema, which is parallel to conduct comprehensive baseline therapy provides patients also modern purpose imunotropnoho the domestic drug Flurenizyd [55].

\subsection{Flumexide and Flupestal}

Flurenizide served as the basis for new liquid medications Flumexide and 1\% antiseptic solution Flupestal for treatment of infectious diseases.

Flumexide (2\% hydrodimexide suspension) combines antibacterial properties of Flurenizide with pharmacological effects of dimexide. Flumexide affects staphylococcus, streptococcus, e.coli, causing cleaning and healing of wounds in case of proinflammatory skin diseases (epidermis and derma). Flumeksyd improves wound healing process in patients with recurrent malignant tumors of the skin, reduces inflammation and promotes the appearance of granulation in the wound and the formation of biological dressings. The drug is recommended for use in surgery [56, 57].

A new liquid dosage form $1 \%$ Flupetsal is a medication for local antisepsis and treatment of puss and inflammatory processes in surgery, dentistry-for complex treatment for acute and chronic alveolitis, in otolaryngology, rheumatology - for treatment of joint syndrome in reactive chlamydia-associated arthritis patients. Flupestal has antimicrobial, anti-inflammatory, immune modulating and antioxidant effect, without causing allergy and irritation. 1\% Flupetsal was tested in veterinary practice for treatment of otodectosis - damage to outer ear caused by acari bites [58-63].

\section{Conclusions}

Flurenizide is an important biomolecule with properties which are optimal for having required pharmacological effect-antimicrobial (antituberculosis, antichlamydia), immune modulating, antioxidant, antiradical, hepatoprotective, anti-inflammatory etc.

Described new dosage forms (solid, soft and liquid), exhibit higher clinical effect. They are intended for the prevention and treatment of hazardous and controlled infectious diseases in medicine and veterinary medicine.

Use Flurenizydu in various dosage forms expand the range of drugs antiviral, antimicrobial and antiseptic action needs to humane and veterinary medicine.

\section{References}

[1] Pat. 23046 C1. MPK6 KL A61K31/05 C07 C35/38. 1998. Antimicrobial Agent. Bull. No. 3, Ukraine.

[2] Certificate Ukraine to Sign Number of Goods and Services 24,424. 2002. "Flurenizyd Pharmaceutical and Medicines that Are Used to People and Animal/Ukraine." No. 99020381; Zayavl.10.02.99, Bull. No. 4, Ukraine.

[3] Petrukh, L. I. 2008. Fluorenes as Tuberculostatics, Flurenizide: Microbiological, Pharmacological and Clinical Aspects. Lviv, 469.

[4] Khomenko, A. G., Golyshevskaya, V. I., Maslova, L. I., Kalmykova, G. N., and Uvarova O. A. 1990. "Chemotherapeutic Efficacy of New TB Tools Flurenizida Experiment." Problems of Tuberculosis 6: 3-6.

[5] Sybirna, R. I., Kreymer, N. Y., Sybirnyy, A.V., and Yuhymenko, I. Y. 1995. "Application Flurenizydu in Hemioterapiyi Experimental Mycobacterial Infections." Presented at Natsionalnoho Congress Farmakoloriv, Poltava, Ukraine.

[6] Sibirny, A. V. 1995. "The Impact on Microorganisms Flurenizydu." In Proceedings of Conference Faculty Members and Graduate Business Akademiyi, 200-1.

[7] Sibirny, A. V. 1997. "Impact Fluorene Derivatives on the Enzymatic Activity of Mycobacterium.” Actual Problems of Medicine, Biology, Veterinary and Agriculture Hospodarstva 3: 44-5.

[8] Sybirna, R. I., Sibirny, A. V., and Yukalo, V. E. 2000. Research Flurenizydu Therapeutic Activity in Experimental Tuberculosis." Pharmaceutical Zhurnal 2: $72-5$.

[9] Sybirna, R. I., Kramer, N. Y., Sibirny, A. V., and Yukhimenko, I. E. 1995. "Use Flurenizydu in 
Experimental Chemotherapy of Mycobacterial Infections. Modern Problems of Pharmacology." Presented at National Congress of pharmacologists, Kyyiv, Ukraine.

[10] Sibirny, A. V. 2002. "Antibacterial Effect of New Substances on Fluorenilidenu Nonspecific Respiratory Microflora.” Presented at VI Intern. Honey. Congré. Stud. and Mol., Vchenyh, Ternopil.

[11] Sibirny, A. V. 2003. "Frequency Selection and Sensitivity Mycobacterioses Pathogens and Opportunistic Infections of the Respiratory and Novosyntezovanyh to Known Drugs." Biol. Science Spec. 03.00.07, microbiology.

[12] Mykhalyk, O. I. 2003. "Development, Research and Standardization of Solid Dosage Forms Flurenizydu." Ph.D. thesis, Pharmaceutical Sciences, Kharkiv.

[13] Petruh, L. I., Kozhakina, I. P., Borodina, L. O., Danevych, O. I., Heorhiyevskyy, V. P., Mykhalyk, O. I., et al. 2003. Pat. 36112 C2/UA/No. 99116012. Tablet Antimicrobial Action. The Application Number 99116012, Appl. 11/02/99, Bull. No. 1.

[14] Mykhalyk, O., Pronyuk, A. 2001. "Tablet Form of TB Drugs." Presented at V International Congress of Medical Students and Young Scientists Dedicated to the 10th Anniversary of Independence of Ukraine, Ternopol, Ukraine.

[15] The Cabinet of Ministers of Ukraine. 2001. 1,482 Number, M. Kyiv. On Approval of the National List of Main (Vital) Medicines and Medical Devices. Kyiv: Cabinet of Ministers of Ukraine.

[16] The Cabinet of Ministers of Ukraine.2006. 400 Number, M. Kyiv. On Approval of the National List of Essential Medicines and Medical Devices. Kyiv: Cabinet of Ministers of Ukraine.

[17] Ilnytskyy, I. G., Panasiuk, O. V., and Petrukh, L. I. 1993. "The Results of Clinical Trials Flurenizydu in Pulmonology Practice." Problems of Tuberculosis 3: 17.

[18] Ilnytskyy, I. G., Petrukh, L. I., Chulovska, W. B., Frayt, W. M., Zaveruha, O. Y., and Kozubskyy, Y. O. 1993. The Immediate Results of Flurenizydu in the Treatment of Newly Diagnosed Patients with Pulmonary Tuberculosis. Lviv: Nauk. Methodological Aspects Fiziolohiyi.

[19] Panasyuk, A. V., Bylko, I. P., and Mykhalchuk, V. I. 1993. "Clinical Evaluation of New Pharmacological Sredstva of the Effectiveness Protyvotuberkuleznoho Action Flurenyzyda with Infiltrative Pulmonary Tuberculosis in the Decay Phase with Bakteryovыdelenyem.” In Actual Problems of Clinical Pharmacology. Presented at Eng. Science. Conf. with the Participation of SND, Vinnytsya, Ukraine.

[20] Ilnytskyy, I., Kozubskyy, Y., Geleta, N. and Petrukh, L. I. 1994. "Therapeutic Effectiveness Flurenizydu Clinic Teenage TB." Presented at I Congress of the World
Federation of Ukrainian Pharmaceutical Tovarystv, Lviv, Ukraine.

[21] Ilnytskyy, I. G., Petrukh, L. I., Chulovska, V. B., and Kozubskyy, Y. O. 1994. "Experience Flurenizydu Use in the Treatment of Tuberculosis." In Proc. Ext. V Congress SFULT, 71.

[22] Ilnytskyy, I. G., Hud, M. V., Mykulyak, Y. U., and Kozubskyy, Y. O. 1995. "The Immediate Results of Testing in Pulmonology Practice Flurenizydu.” Topical Issues of Practical Medicine 1: 13-4.

[23] Kozubskyy, Y. O. 1997. "Efficiency of Chemotherapy of Pulmonary Tuberculosis in Adolescents Using Isoniazid and Flurenizydu." Ph.D. thesis, Honey. Nauk. K., 24.

[24] Kostik, O., Boris, V., Petrukh, L., Romanhenko, M., Ordynsky, M., Yevtushok, A., et al. 1997. “Application for Flurenizydu Hemioprofilaktyky Tuberculosis in Children." In Proceedings Nauk. and Practical. Conf., Dedicated to the 25th Anniversary of the Lviv City Clinical Emergency Hospital "Aspects of Medical Emergency".

[25] Mazhak, K. D., Kostya, O. P., Petrukh, L. I., Kovalenko, M. M., Platonova, I. L., Lapovets, N. Y., et al. 1997. "Features of Metabolic Processes in Hemioprofilaktytsi Flurenizydom Tuberculosis in Children." In Proceedings Nauk. and Practical. Conf., Dedicated to the 25th Anniversary of the Lviv City Clinical Emergency Hospital "Aspects of Medical Emergency".

[26] Mykhalchuk, B. I. 1997. "Clinical and Microbiological Substantiation of Flurenizydu Chemotherapy in Patients with Newly Diagnosed Destructive Pulmonary Tuberculosis.” In Honey, Nauk. K., 19.

[27] Kostik O. 2000. "Tuberculosis in a Teaching Age Children Residing in Contaminated Territories Radionuklidamy." Ph.D. thesis, Institute ftyziatriyi and pulmonolohiyi University, Kyiv, Ukraine.

[28] Weaver, O. A., Mira, A. Z., Pleshakova, M. E., and Petrukh, L. I. 2002. "Farmakolorichni Properties of Specific Drugs for Tuberculosis Hemioterapiyi." Presented at All-Ukrainian Nauk. and Practical. Conf. "Pharmacy XXI Century", Kharkiv, Ukraine.

[29] Pronyuk, A. V. 2003. "Development and Standardization of Flurenizydom Suppositories." Ph.D. thesis, Pharmaceutical Sciences, Kharkiv.

[30] MOH Ukraine. 2001. Registration Certificate for Vaginal Suppositories of 0.1 Flurenizydome, No. 10, Production of "Monfarm". No. R.10.01/03849 of 10/30/01. Kyiv: MOH Ukraine.

[31] Order Ministry of Health of Ukraine. 2002. The List of Drugs Approved for Use in Ukraine, Prescription from Pharmacies and Pharmacy Items-Flurenizyd. Flurenizide. Dosage Form: Vaginal Suppositories of $0.1 \mathrm{~g}$ No. $10(5 \times 2)$ in Blisters. MOH Ukraine No. 233 
25.07.97 (ZA444-97) in the Wording of the Order Ministry of Health of Ukraine No. 181 21.05.2002, Registered in Min. Justice of Ukraine 01.04.02, No. 494/6782, Kyiv.

[32] Petrukh, L. I., and Pavlenko, A. V. 2015. Chlamydia. Flurenizyd. Suppositories Antyhlamidiynoyi Action-Manual. Lviv: Printing Center Lviv Polytechnic.

[33] Petrukh, L. I., and Pavlenko, A. V., eds. 2012. Flurenizyd from Synthesis to Drug Standards in the Treatment of Tuberculosis and Chlamydia. Thematic Bibliotr. Pokazhch. (1990-2011 Years). Lviv: Shevchenko Scientific Society.

[34] Order Ministry of Health of Ukraine. 2009. "Formulary Guide to the Use of Drugs in Obstetrics, Gynecology." In MOH Ukraine of 14.01.2009 No. 8 Years.

[35] Order Ministry of Health of Ukraine. 2009. "On Approval of the Formulary Guide for Using Drugs in Urology, Andrology, Sexual Pathology, Nephrology." In MOH Ukraine No. 12 from 14.01.2009.

[36] Blikhar, V. E., Maltsev, V. I., and Morozov, A. M., eds. 2012. "State Form Drugs." In MON Ukraine from 28.03.2012 No. 209.

[37] Abrahamovych, A. A., and Zhurayev, R. K. 2004. "The First Experience of Flurenizydu in Treatment of Patients with Reactive Arthritis Chlamydial Etiology." Ukrainian Journal of Rheumatology 4 (18): 14-6.

[38] Boychuk, A. V. 2001. "Diagnosis and Treatment of Inflammation of the Uterus and Its Appendages, Depending on the Immune, Hormone and Antioxidant Systems of the Body. In Dokt.med.nauk, Specialty 14.01.01, Obstetrics and Gynecology, Kyiv.

[39] Buyanov, O. V., Boychuk, A. V.. Kulinich, T. I., Petrukh, L. I., and Pronyuk, O. V. 2005. "Flurenizyd in Treatment of Urogenital Chlamydia in Women." In Dosage Flurenizydu as Vaginal Suppositories in Treatment Combined Chlamydial Infections in Gynecology. Medical City, Obstetrics and Gynecology: Inform. Bulletin 2: 39.

[40] Denisenko, O., Buyanov, O. V., and Kukhta, A. P. 2001. "Flurenizyd in Treatment of Urogenital Chlamydia in Women." Galician Medicinal Bulletin 8 (2) 83-4.

[41] Hevko, A. V. 2003. "Clinical and Pathogenetic Substantiation of Flurenizydu Imunomodulyuvalnoho and as a Means Antyhlamidiynoho in Patients with Chronic Pyelonephritis." In Honey Sciences, Specialty 14.01.02, Internal Diseases. Ivano-Frankivsk: Ivano-Frankivsk State Medical Academy, 19.

[42] Zhurayev, R. K. 2007. "Clinical and Immunological Study Flurenizydu Use in Treatment of Patients with Reactive Arthritis, Combined with Chronic Urogenital Chlamydiosis." In Kand. Med. Sciences 14.01.02, Internal Diseases, Kyiv, 20.

[43] Korda, I. V. 2000. "Impact Flurenizydu the Functional
State of the Immune System in Women after Cesarean Section." Journal of Research 2: 55-6.

[44] Tailor, T. V., Korda, I. V. 2001. "Correction Flurenizydom Violations Oxidative Processes in Women with Risk Factors for Infection after Cesarean Section." Medical Chemistry 3 (4): 69-71.

[45] Tailor, T. V. 2002. "Impact Flurenizydu Content of Middle Mass Molecules in the Blood Plasma of Women with Risk Factors for Infectious Complications after Cesarean Section.” Medical Chemistry 3 (4): 69-71.

[46] Franchuk, A. U., Boychuk, A. V., Kulinich, T. I., Flehner, V. M., and Malanchuk, L. M. 2001. "Flurenizyd in Treatment of Background Cervical Diseases." Achievements of Clinical and Experimental Medicine 6: 74.

[47] Kulinich, T. I. 2002. "Antyhlamidiynyy New Drug in the Treatment of Inflammation of Internal Genital Organs of Women." Bulletin Research 2 (Annex): 259-60.

[48] Petruch, L., Mychalyk, O., Kovalenko, M., and Petruch, A. 2004. "The Ukrainian Antituberculosis and Antimicrobic Drug-“Flyrenizid"." Presented at XIX Naukowy Zjezd Polskiego Towarzystwa Farmaceutycznego "Farmacja-Tradycja i Novoczesność", Wrocław, Poland.

[49] Medical Index. 2005. "Dosing Flurenizydu as Vaginal Suppositories in Treatment Combined Chlamydial Infections in Gynecology." Obstetrics and Gynecology: Newsletter 2: 39.

[50] Petrukh, L. I. 2007. "Flurenizyd in the Treatment of Chlamydial Infections." Ukrainian Journal of Dermatology, Venereology, Cosmetology 1 (24): 85-7.

[51] Petrukh, L. I., Yurevich, V. R., Novitsky, I. J., Yurevich, D. G., and Mykhalyk, O. I. 1997. "Pat. 20624 A/UA/ Eye Ointment to Treat Burns and Bacterial Inflammation of the Cornea." In The Application Number 97031046, Appl. 11/03/97, Byul. No. 1.

[52] Petrukh, L. I., Yurevych, V. R., Novytskyy, I. Y., and Yurevych, D. H. 1998. "Flurenizydu Efficiency in the Treatment of Experimental Burns Eye." Presented at Scientific Conference Oftalmoloriv Dedicated to the 90th Anniversary of Academician. N.O. Puchkovskoyi, Odessa.

[53] Mykhalyk, O. I., and Yurevich, V. R. 1999. "Medications to Treat Bacterial Lesions of the Chemical Burns and Eye.” Presented at V National Congress of Pharmacists of Ukraine, Kharkiv.

[54] Yurevych, V. R., Novytskyy, I. Y., Yurevych, D. H., and Kachmaryk, O. R. 2003. "Efficacy of 1\% Flurenizydovoyi Ointment in Treatment of Patients with Bacterial Keratitis Burns and Eye." Presented at Memorial Scientific and Practical. Conf. Students and Young Scientists M.Korytko Memory, Lviv. 

Controlled Infectious Diseases

[55] Turkevych, O. 2007. "Treatment of Dermatitis and Eczema Workers in Chemical Industry Based Skin and Physiological State of Some Indicators of Homeostasis." In Honey. Science on Specialty 14.01.20, Shkirni and Venereal Diseases. Kyiv: National Medical University, 20.

[56] Petrukh, L. I., Kunovskyy, V. V., and Andryushchenko, V. P. 1997. "Pat. 195504 A/UA Tools for Treatment of Purulent Inflammation of the Skin and Subcutaneous Tissue." In The Application Number 93007738, Appl. 21.12.93; Publish 12.25.97. Bull. No. 6.

[57] Kunovskyy, V. 1998. "The Use of New Medicinal Product Flumeksydu in Complex Hirurrichnomu Likuvanni Hniyno Inflammatory Diseases and Skin Pidshkirnoyi Base." In Honey. Science on Specialties 14.01.03, Hirurhiya. Lviv: Lviv National Medical University.

[58] Petrukh, L. I., Saldan, Y. R., Gerashchenko, I. I., Saldan, V. I., Mykhalyk, O. I. 2006. Pat. Ukraine Number 75600/UA/Antiseptic, Application Number 2002129962, Appl. 12/11/02; Bull. No. 5.

[59] Gutor, N. S., and Mykhalyk, O. I. 2006. "Application Flupetsalyu in Hirurrichniy Stomatoloriyi." Current Issues of Pharmaceutical and Medical Science and
Practice. Coll. Articles 15 (3): 532-5.

[60] Petrukh, L. I., Ostrovska, L. L., Mykhalyk, O. I., Ostrovskyy, Y. Z. 2008. Pat. Ukraine Number 82787/UA Use of a Pharmaceutical Composition for the Treatment of Chronic Otodektozu." In Application Number a200613873, Appl. 26/12/06; Bull. No. 9.

[61] Gutor, N. S. 2011. "Optimization Diagnosis, Prevention and Treatment Alveolitiv (Experimentally-Clinical Research)." In Honey. Science on Specialty 14.01.22, Stomatolohiya. Odessa: State Institution "Institute Stomatolohiyi AMI Divide in Ukraine, 20.

[62] Gutor, N., and Mykhalyk, O. 2007. "Robert Rubas Research Antimicrobial Properties 1.0\% Flupetsalyu in Treating Alveolitis." Presented at XI Anniversary International Medical Congress of Students and Young Scientists, Ternopol.

[63] Mykhalyk, O. I., Gutor, N. S., Homzyak, T. V., and Tyahnybok, B. A. 2005. "Creation and Standardization Flupetsalyu for the Treatment of Inflammatory Diseases of Maxillofacial Area. Achievements and Prospects of Development of Pharmaceutical Industry of Ukraine." Presented at VI National Congress of Pharmacists of Ukraine, Kharkiv. 